\title{
Effect of wet-curing on physical properties and proteins of cured ham
}

\author{
ANNA VISY ${ }^{1 *}$ (]), KARINA ILONA HIDAS ${ }^{1}$, ANNAMÁRIA BARKÓ $^{1}$, \\ LIEN LE PHUONG NGUYEN ${ }^{1,2}$, LÁSZLÓ FRIEDRICH ${ }^{1}$ and GÁBOR JÓNÁS ${ }^{1}$
}

\footnotetext{
${ }^{1}$ Institute of Food Science and Technology, Hungarian University of Agriculture and Life Sciences, 1118, Budapest, Hungary

${ }^{2}$ Institute of Biotechnology and Food Technology, Industrial University of Ho Chi Minh City, Ho Chi Minh, 700000, Vietnam
}

\section{CONFERENCE FULL PAPER}

\section{ABSTRACT}

Consuming enough protein is a very important part of a balanced and healthy diet. Complete proteins are those in which all essential amino acids are present. In meat products, like hams, many different reactions occur during ageing and storage. For example, the production of free amino acids or the production of biogenic amines is formed by decarboxylation. In this study, the presence of these amino acids and biogenic amines, as well as the quality properties of cured hams during curing and ageing, were investigated.

The meat samples were immersed into $100 \mathrm{~g} \mathrm{~L}^{-1} \mathrm{NaCl}$ brine. The curing took 20 days, followed by smoking and ageing for 35 days $\left(12^{\circ} \mathrm{C}, 75 \% \mathrm{RH}\right)$. The wet-cured ham samples were analysed for changes in $\mathrm{NaCl}$ concentration (at 3 parts: surface, core, bottom layer). Moreover, color, water activity, denaturation temperature and enthalpy (Differential Scanning Calorimetry), free amino acids (FAAs) and biogenic amines (BAs) were also evaluated.

\section{KEYWORDS}

wet-curing, proteins, amino acids, biogenic amines

\footnotetext{
*Corresponding author. E-mail: visy.anna@phd.uni-szie.hu
} 


\section{INTRODUCTION}

Meat is primarily a protein food, containing high amounts of protein with high biological value. Some essential amino acids are naturally present in sufficient quantities only in meat (Toldrá, 2002). Meat is also a major source of vitamins and minerals and contains most of the B vitamins. Of these, vitamin B12 is essential. With a balanced diet, meat and meat products can provide up to $70 \%$ of vitamin B12 (Dublecz, 2011). Both traditional and modern preservation methods are currently used to ensure that the product retains its organoleptic properties and valuable components for as long as possible.

Curing has been used for centuries to preserve food, especially meat. During the curing process, salt, sugar, nitrite or nitrate and other substances are added to the product to preserve it and to develop its flavour and color (Keenan, 2016). There are two main forms of traditional curing: dry- and wet-curing. In the traditional curing the meat is usually immersed in simple brine, which reduces the water content of the meat due to osmotic dehydration (Lawrie and Ledward, 2006). Perhaps the biggest disadvantage of traditional methods nowadays is that they are time-consuming, some products can take years to cure. In the case of curing, both physical and chemical processes take place in the product, which strongly determine the quality of final product. These changes are important for the taste, texture, colour and protein formation.

Mayer et al. (2010) found that biogenic amines are small molecular weight organic bases. They can have different structures, which are: aliphatic (putrescine, cadaverine, spermidine), aromatic (tyramine, phenylethylamine) or heterocyclic (histamine, tryptamine). They are formed during the metabolic processes of animal, plant and microbial cells. They are found in high amounts in foods where microbial activity is present, such as in wine, fermented meats, fish, vegetables and cheese. Typically, these nitrogen-containing compounds are formed by microbial decarboxylation and transamination of amino acids to aldehydes or ketones. During ageing or possible degradation, if the reaction conditions are favourable in terms of enzyme activity, the growth of microorganisms leads to the decarboxylation of free amino acids, resulting in the production of biogenic amines (Fiechter et al., 2013). The amount of FAAs can be reduced by chemical and enzymatic reactions. These lead to the formation of secondary products as substrates and/or microbial amino acid decarboxylase activity and consequently BA production (Ruiz et al., 1999). Therefore, the aim of this study was to investigate the presence of biogenic amines during curing.

\section{MATERIALS AND METHODS}

\section{Experiment}

Pork loin (Longissimus dorsi) obtained from a local slaughterhouse was used to carry out the experiment. Pork loin with a relatively homogenous muscle was chosen. The meat samples were cured in brine containing $100 \mathrm{~g} \mathrm{~L}^{-1} \mathrm{NaCl}$ for 20 days. After the wet-curing the samples were smoked with beech wood at about $27^{\circ} \mathrm{C}$. The smoking was followed by ageing for 35 days $\left(12{ }^{\circ} \mathrm{C}, 75 \% \mathrm{RH}\right)$. During the experiment, the $\mathrm{NaCl}$ content, color, water activity, denaturation temperature and enthalpy (differential scanning calorimetry) were measured on day $0,1,4,813$, 20, 27, 34, 41, 48 and 55. The free amino acids (FAAs) and biogenic amines (BAs) were measured only during the ageing period. 


\section{$\mathrm{NaCl}$ content determination}

$\mathrm{NaCl}$ concentrations of samples were determined by titrating chloride anions in sample solutions with silver nitrite using the Mohr method as described by Kameník et al. (2017).

This formula was used to calculate the salt content:

$$
\mathrm{NaCl} \text { content }(\%)=\frac{V^{*} N^{*} F^{*} 0.0585^{*} 100}{m}
$$

$V$ : consumption of $0.1 \mathrm{~N} \mathrm{AgNO}_{3}$ in titration (mL)

$\mathrm{N}$ : normality of $\mathrm{AgNO}_{3}$

$F$ : factor of $0.1 \mathrm{~N} \mathrm{AgNO}_{3}$

$m$ : mass of sample $(g)$.

$\mathrm{NaCl}$ content was measured at 6 points of the sample. These areas were divided into 3 parts. With this sampling it was also possible to determine the salt content at 3 points: on the surface, in the core and in the bottom part (above fat) (Fig. 1). The fat layer was approx. $15 \mathrm{~mm}$, the meat layer was approx. $80 \mathrm{~mm}$.

\section{Color measurement}

Objective color was measured with Minolta ChromaMeter CR-400 (Konica Minolta Inc., Japan) at 3 different points on the surface and cross-section of meat samples. The results of the color measurement were evaluated in the CIE Lab system, in which the three color factors were lightness $\left(L^{*}\right)$, redness $\left(a^{*}\right)$ and yellowness $\left(b^{*}\right)$.

\section{Water activity measurement}

The water activity of the samples was measured using a LabMaster AW equipment (Novasina AG, Switzerland). The measurement was performed from 3 different points of the sample (2 sides and core of the loin).

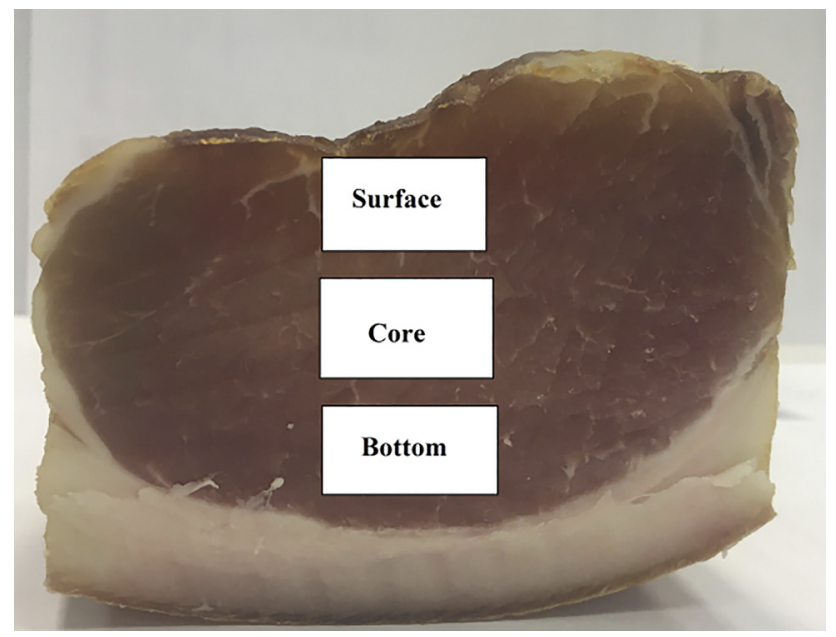

Fig. 1. Sampling of the meat 


\section{Differential scanning calorimetry}

Micro DSC II CS32 Calorimeter Vessels Setaram (Setaram Inc. Caluire-et-Cuire, France) was used to determine the denaturation of main meat proteins. Samples for DSC measurements were cut from the centre of the hams $(0.220 \pm 0.005 \mathrm{~g})$ then were placed into metal pans and hermetically closed. Scanned range was from 25 to $90^{\circ} \mathrm{C}$ with $1^{\circ} \mathrm{C} \mathrm{min}^{-1}$ heating rate. The reference sample was distilled water.

\section{Chromatographic determination of amino acids and biogenic amines}

The qualitative and quantitative determination of amino acids and biogenic amines was carried out with an AAA 400 equipment (Ingos Ltd., Czech Republic). This Automatic Amino Acid Analyzer is a compact automatic liquid chromatograph based on ion exchange column chromatography. Using buffers provided by the producer, separation is performed by step gradient elution. The post-column derivatisation was performed by a ninhydride reaction followed by detection at $570 \mathrm{~nm}$ and for proline at $440 \mathrm{~nm}$. The evaluation was performed with CHROMULAN V. 0.82 program. About $5 \mathrm{~g}$ sample was required to perform the measurement. Samples were obtained from the centre of each meat sample.

\section{Statistical analysis}

Statistical analysis was performed by IBM Statistics 24 software. The investigated factors were time and meat layer (surface, centrum, bottom). Differences were considered significant at the $P<0.05$ level. Homogeneity of measured values was checked by Levene's test $(P<0.05)$ and the significant differences amongst days and layers were analysed by Tukey HSD probe $(P<0.05)$.

\section{RESULTS}

\section{$\mathrm{NaCl}$ content}

The $\mathrm{NaCl}$ content was measured at three different points in the sample to observe salt diffusion. The curves are almost linear (Fig. 2). It is clear that the changes in $\mathrm{NaCl}$ content measured in the different layers show a similar trend. The increase of $\mathrm{NaCl}$ content was significant $(P<0.05)$ in all layers.

As expected, the salt content of the surface layer increased more rapidly during the curing phase (day 20), followed by a more significant increase in the core during the ageing period. This can be explained that during curing, the salt diffusion starts more slowly and therefore the salt content of the surfaces in direct contact with the brine is higher. Therefore, from the surface to the bottom of the sample, the salt content was progressively lower, but there was no significant difference $(P<0.05)$ between the average $\mathrm{NaCl}$ content of the layers. During the ageing, however, the salt content of the different layers becomes almost equal by the end of the experiment. At day 55, the salt content of the cured ham was above the required concentration of $5 \%$ (average salt content of about $6.8 \%$ ).

\section{Color}

The changes in the lightness $\left(\mathrm{L}^{\star}\right)$ are shown in Fig. 3. It can be seen that the cross-section remained darker to the end of the curing period, as the salt content of the brine made the surface of the meat paler. 


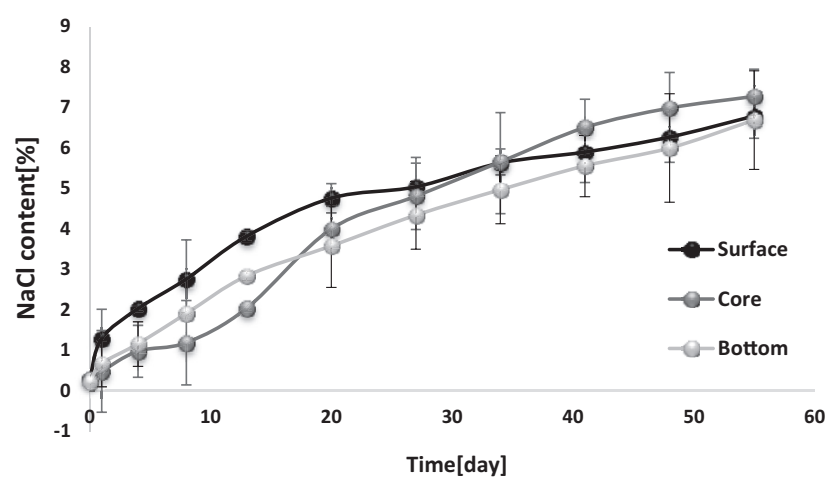

Fig. 2. Changes in $\mathrm{NaCl}$ content measured on the surface, core and bottom of cured ham during the experiment

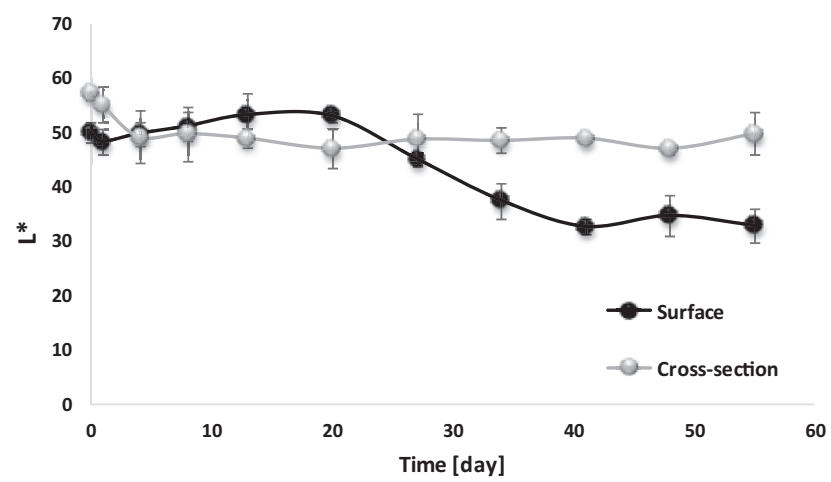

Fig. 3. Changes in the $L^{*}$ (lightness) value of cured ham on the sample surface and on the cross-section

From day 20 onwards, the surface area values showed a decreasing trend. This is due to the smoking process, which is responsible for the sudden darkening of the samples through color development. Also, the colors have darkened during ageing, as shown by the further decrease in $\mathrm{L}^{*}$ values. This is explained by the fact that during the ageing period the samples are constantly drying, their moisture content decreases and their color is dark. The difference in the lightness between the surface and the cross-section was significant $(P<0.001)$.

The changes in the redness $\left(\mathrm{a}^{*}\right)$ are shown in Fig. 4 . The values measured on the surface are also higher. After day 20, a significant change is seen, which can also be explained by smoking. The effect of smoking on color is striking, as it makes the hams have reddish color, typical of smoked products. However, similarly to the $\mathrm{L}^{*}$ values, there was no significant change in $\mathrm{a}^{*}$ values for the cross-section. In the ageing phase, the measured values showed an increase, which was due to the continuous penetration of salt and its effect on color.

The change in $b^{*}$ is not shown because it is not relevant for meat. 


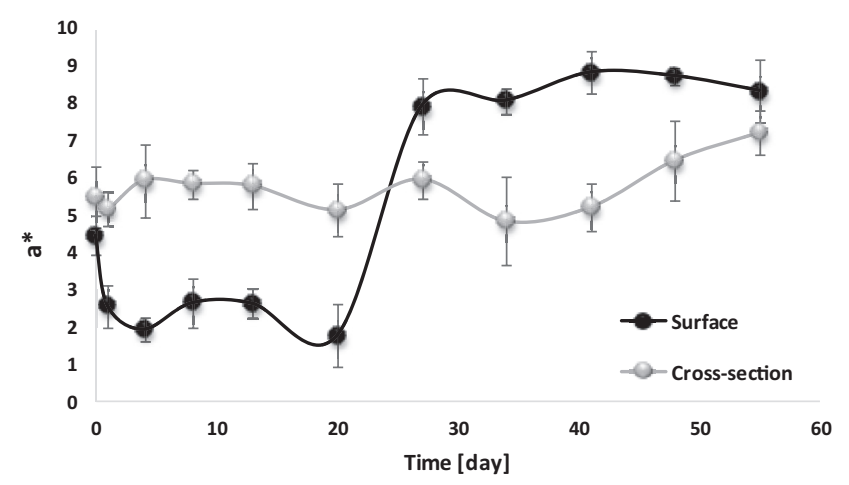

Fig. 4. Changes in the $\mathrm{a}^{\star}$ (redness) value of cured ham on the sample surface and on the cross-section

\section{Water activity}

Water activity is the fraction of the total water content in food that is available to microbes and therefore closely related to the microbiological stability and shelf life of the product. In simple terms, it is the amount of "free" water in food. The lower the $a_{w}$ value, the more protected the product is against microbiological spoilage.

The diagram (Fig. 5) shows that during the curing process the brine diluted the muscle cells by day 4 , and from day 8 onwards, the dehydrating property of $\mathrm{NaCl}$ can be seen. The $a_{w}$ value decreased to a greater extent in the ageing phase. It was probably due to the drying of the samples and the ageing process. However, the safe level below 0.90 was reached only on day 55 . During curing, the aim is to achieve this value $(<0.90)$ as soon as possible. This can be accelerated by changing the ageing parameters.

\section{Differential scanning calorimetry (DSC)}

The DSC thermograms of cured hams were analysed to establish the effect of curing on protein denaturation (Fig. 6). The diagram shows the heat flow curves of the samples measured on days

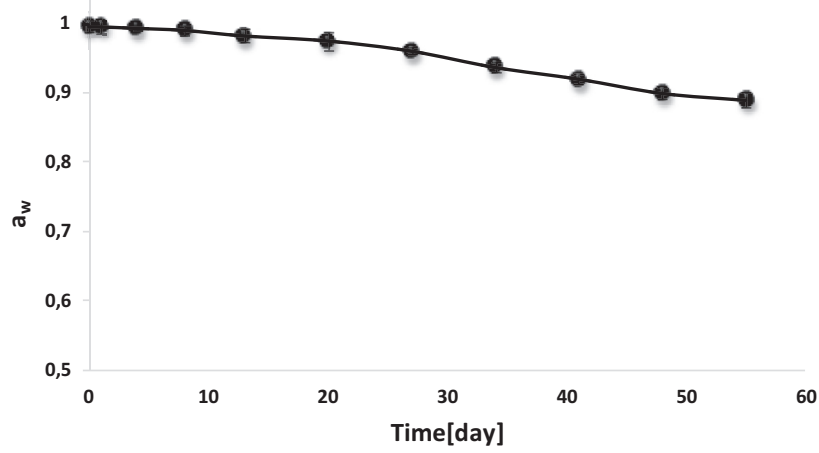

Fig. 5. Changes in water activity of cured ham during the experiment 


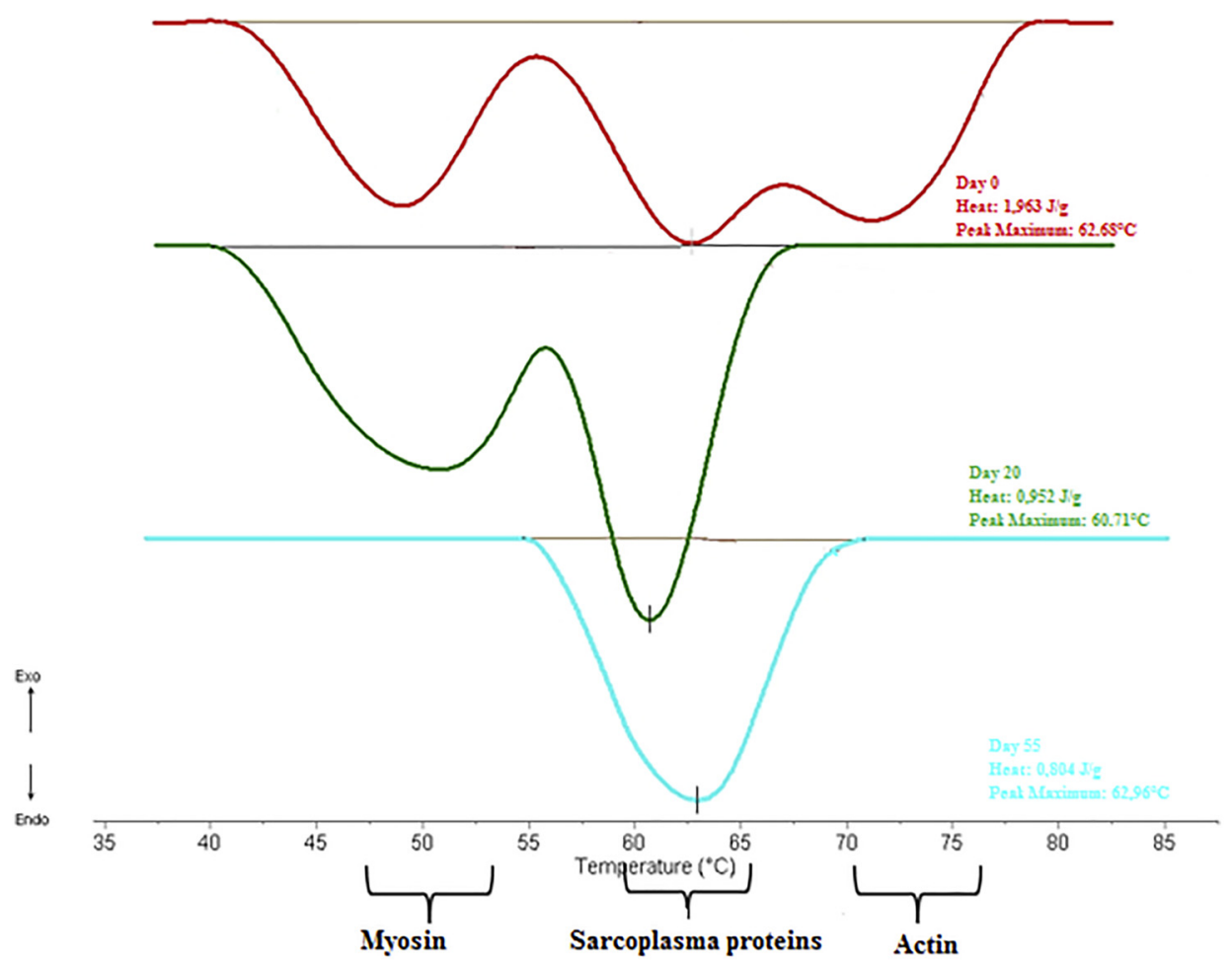

Fig. 6. The heat flow curves of cured ham measured on days 0,20 and 55

0, 20 and 55. DSC can be used to study the structural changes in the proteins of the sample, i.e., denaturation, coagulation and aggregation can be well monitored. In case of raw meat the thermal peak $\left(T_{\max }\right)$ can be determined for three proteins: myosin $\left(58^{\circ} \mathrm{C}\right)$, sarcoplasmic proteins and collagen $\left(66^{\circ} \mathrm{C}\right)$, and actin $\left(80^{\circ} \mathrm{C}\right)$. Fernández-Martín (2007) concluded that the evolution of the denaturation peaks obtained from DSC measurements may be related to the denaturation of individual muscle proteins and to changes in the structure of the meat. This suggests that as the salt content increased, the proteins were probably denatured or aggregated.

The heat flow curves that at the end of curing, the denaturation peak of actin had completely disappeared, while at the end of ageing, only the peak of sarcoplasmic proteins remained. Increasing the salt content therefore clearly affects the structure of proteins. This can be seen from the change in denaturation enthalpy values (Table 1). As the salt content increased, this value decreased significantly, suggesting that the amount of denaturable proteins in the meat is decreasing.

\section{Changes in the amount of free amino acids}

During maturation, 20 free amino acids were determined in the samples and are shown in Table 2. Amino acids directly contribute to the flavour and quality of meat products, and the compounds they produce (ammonia, amines, carbonyls, acids) are also very important in the 
Table 1. Denaturation enthalpy values obtained from DSC measurements on days 0,20 , and 55 and the $\mathrm{NaCl}$ content of the samples on those days (average of three measurements \pm standard deviation)

\begin{tabular}{lc}
\hline Entalphy $\left[\mathrm{J} / \mathrm{g}^{-1}\right]$ & $\mathrm{NaCl}$ content $[\%]$ \\
\hline $1.963 \pm 0.4$ & $0.29 \pm 0.3$ \\
$0.952 \pm 0.6$ & $4.76 \pm 0.5$ \\
$0.804 \pm 0.4$ & $5.90 \pm 0.4$ \\
\hline
\end{tabular}

Table 2. Changes in free amino acids during ageing

\begin{tabular}{|c|c|c|c|c|c|c|c|}
\hline \multirow[b]{2}{*}{ Name } & \multicolumn{7}{|c|}{ Measured values of free amino acids during ageing $\left(\mathrm{mg} / \mathrm{g}^{-1}\right)$} \\
\hline & week 0 & week 1 & week 2 & week 3 & week 4 & week 5 & week 6 \\
\hline Aspartic acid & 16.408 & 18.388 & 19.913 & 27.680 & 38.627 & 48.326 & 54.715 \\
\hline Treonine & 18.154 & 25.653 & 34.722 & 60.865 & 61.899 & 63.459 & 65.621 \\
\hline Serine & 23.169 & 28.969 & 47.770 & 74.947 & 100.352 & 109.275 & 127.417 \\
\hline Asparagine & 77.678 & 70.915 & 119.677 & 412.115 & 335.351 & 433.328 & 501.517 \\
\hline Glutamic acid & 45.121 & 52.427 & 100.866 & 138.296 & 152.674 & 181.664 & 183.073 \\
\hline Glutamine & 50.569 & 54.202 & 17.698 & 24.382 & 30.823 & 80.894 & 141.245 \\
\hline Proline & 13.978 & 6.543 & 41.570 & 23.511 & 73.308 & 83.548 & 97.575 \\
\hline Glycine & 35.056 & 31.703 & 46.858 & 80.424 & 84.819 & 104.923 & 129.928 \\
\hline Alanine & 55.384 & 57.590 & 96.496 & 149.715 & 171.507 & 201.456 & 251.886 \\
\hline Valine & 25.321 & 31.039 & 39.492 & 70.937 & 105.503 & 115.326 & 133.792 \\
\hline Cysteine & 0.594 & 0.547 & 8.172 & 20.024 & 17.433 & 23.453 & 32.151 \\
\hline Metionine & 20.928 & 22.276 & 37.414 & 56.626 & 75.761 & 87.721 & 104.709 \\
\hline Cystathionine & 0.689 & 0.437 & 1.579 & 4.386 & 2.086 & 5.136 & 6.859 \\
\hline Isoleucine & 13.565 & 17.031 & 31.278 & 53.115 & 63.000 & 69.945 & 74.934 \\
\hline Leucine & 37.760 & 46.145 & 74.825 & 124.252 & 171.116 & 196.986 & 226.145 \\
\hline Tyrosine & 22.096 & 24.124 & 46.312 & 72.464 & 105.308 & 125.678 & 133.094 \\
\hline Phenylalanine & 18.713 & 20.358 & 35.169 & 55.000 & 72.233 & 87.736 & 101.534 \\
\hline Lizin & 7.873 & 9.080 & 55.148 & 70.059 & 102.451 & 114.952 & 128.068 \\
\hline Histidine & 293.984 & 131.326 & 169.751 & 267.030 & 228.309 & 298.365 & 371.112 \\
\hline Arginine & 66.163 & 31.165 & 47.481 & 90.088 & 122.058 & 152.946 & 177.871 \\
\hline Total & 843.204 & 679.919 & 1072.191 & 1875.914 & 2114.618 & 2585.117 & 3043.243 \\
\hline
\end{tabular}

development of the flavour of the product. The decarboxylation of free amino acids results in the production of amines. During decarboxylation, the following transformations occur: histidine to histamine, tyrosine to tyramine, ornithine to putrescine, lysine to cadaverine, tryptophan to tryptamine, phenylalanine to phenylethylamine.

The table shows that the amount of free amino acids increased from week to week. This is due to the activity of meat aminopeptidases (Toldrá, 2006) and microbial proteases (Durá et al., 2004). The rate of increase is almost the same for each amino acid. In the samples histidine and asparagine were found in the highest amounts. There were also higher levels of alanine, arginine, glutamic acid, glutamine, glycine and leucine. Glutamic acid, glycine and cysteine are precursors of glutathione, the most important low molecular weight antioxidant in the human body (Simon-Sarkadi, 2019). Tyrosine and tryptophan are aromatic amino acids, which were only 
present in small amounts in the samples. Meat usually contains a lot of threonine, but it was not present in high levels in the samples. The lowest amounts were lysine, cysteine and cystathionine. Lysine is generally present in high amounts in foods of animal origin.

Virgili et al. (2007) found that FAAs and BAs increased even after 23 months of ageing at 5\% salt content and water activity below 0.9 . In contrast to our results, there was no increase in arginine in that experiment.

The amount of free amino acids is also affected by, among other things, the smoking of hams (Martuscelli et al., 2009). It was found that mild and intense smoked hams had fewer free amino acids than non-smoked products. However, experience showed that the free amino acid composition did not significantly affect the organoleptic properties of hams.

\section{Changes in biogenic amines}

The changes in biogenic amine content measured in cured hams during the ageing period are shown in Fig. 7. The identification of biogenic amines is important as they can cause harmful physiological effects when consumed in higher quantities.

Polyamines, such as putrescine, cadaverine and the spermin and spermidine found in the sample, increase the toxicity of histamine and tyramine. Although histamine was not detected in the sample, histidine was present in high amounts among the free amino acids. This histidine, if storage had continued, would probably have turned into histamine. Histamine can cause low blood pressure, indigestion and headaches in humans at high levels.

Some research suggests that the amount of biogenic amines may be influenced by the salt content of hams. Laranjo et al. (2017) found higher levels of cadaverine, histamine and tyramine in products with lower salt content (3\%). However, histamine levels remained at low level.

Spermine is produced from spermidine, which is produced from putrescine. In general, food made from vegetables contains more of them. The diagram clearly shows that the amount of spermidine is minimal. Spermine was present in higher amounts, but it was also negligible. The average amount of total biogenic amines in the hams was $0.024 \mathrm{mg} / \mathrm{g}^{-1}$. This is very low, probably due to the short ageing time for formulation the biogenic amines.

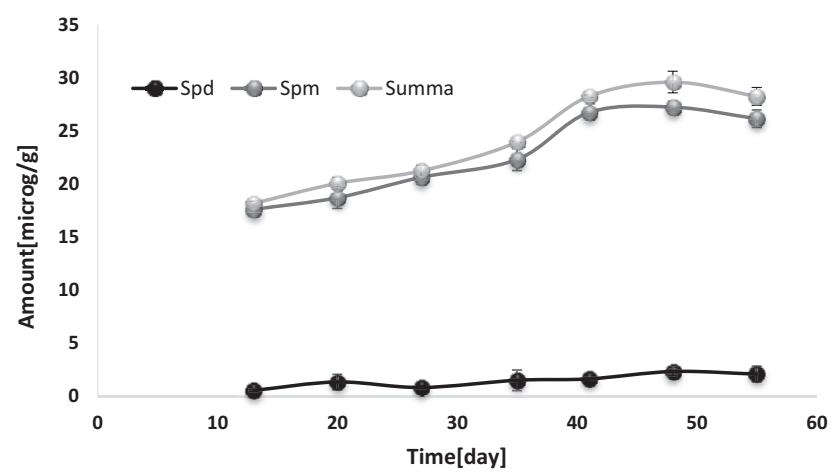

Fig. 7. Changes in biogenic amines during ageing 


\section{CONCLUSION}

By performing the experiment, we obtained the information about the salt content, the color, the water activity, the protein denaturation and the free amino acids and biogenic amines of wetcured ham during the curing and ageing process. During the curing phase, the $\mathrm{NaCl}$ content of the surface increased faster than in the core and in bottom of the samples. However, at the end of the experiment (day 55), there was salt equalization between the different layers. In addition, the color of the cross-section remained darker compared to the surface.

The water activity decreased below 0.90 at day 55, that means a safe product. But it may be necessary to change the ageing conditions in order to shorten the ageing period. Increasing in $\mathrm{NaCl}$ content affected the structure of meat proteins. Protein denaturation was observed from 20 days, thereby the meat loses its raw character, so it is converted to edible form.

The biogenic amine content of the meat was very low during ageing. This can probably be explained by the short time of 6 weeks for the production of biogenic amines.

\section{ACKNOWLEDGEMENT}

The Project is supported by the Doctoral Scool of Food Sciences of Hungarian University of Agriculture and Life Sciences. We owe the colleagues of the Capriovus Ltd. all thanks. Our research is supported by EFOP-3.6.3-VEKOP-16-2017-00005 project, for which we are very thankful.

\section{REFERENCES}

Dublecz, K (2011). Állati termékek táplálkozás-élettani szerepe. Pannon Egyetem, Kaposvár, Hungary.

Durà, M. A., Flores, M., and Toldrà, F. (2004). Effect of Debaryomyces spp. on the proteolysis of dryfermented sausages. Meat Science, 68: 319-328.

Fernández-Martín, F. (2007). Bird muscles under hydrostatic high-pressure/temperature combinations. Journal of Thermal Analysis and Calorimetry: 285-290.

Fiechter, G., Gerald, S., and Helmut, K. M. (2013). Application of UHPLC for the simultaneous analysis of free amino acids and biogenic amines in ripened acid-curd cheeses. Journal of Chromatography B, 927 (2013): 191-200.

Kameník, J., Saláková, A., Vyskočilová, V., Pechová, A., and Haruštiaková, D. (2017). Salt, sodium chloride or sodium? Content and relationship with chemical, instrumental and sensory attributes in cooked meat products. Meat Science, 131: 196-202.

Keenan, D. (2016). Pork meat quality, production and processing on. Encyclopedia of Food and Health, pp. 419-431.

Laranjo, M., Gomes, A., Agulheiro-Santos, A. C., Potes, M. E., Cabrita, M. J., Garcia, R., Rocha, J. M., Roseiro, L. C., Fernandes, M. J., Fraqueza, M. J., and Elias, M. (2017). Impact of salt reduction on biogenic amines, fatty acids, microbiota, texture and sensory profile in traditional blood dry-cured sausages. Food Chemistry, 218: 129-136. 
Lawrie, R. A., and Ledward, D. A. (2006). Lawrie's meat science, 7th ed.. Woodhead Publishing, Cambridge. ISBN 10: 1-84569-161-X (e-book).

Martuscelli, M., Pittia, P., Casamassima, L. M., Manetta, A. C., Lupieri, L., and Neri, L. (2009). Effect of intensity of smoking treatment on the free amino acids and biogenic amines occurrence in dry cured ham. Food Chemistry, 116(4): 955-962.

Mayer, H. K., Fiechter, G., and Fisher, E. (2010). A new ultra-pressure liquid chromatography method for the determination of biogenic amines in cheese. Journal of Chromatography, 1217: 3251-3256.

Ruiz, J., Garcia, C., Diaz, M. C., Cava, R., Tejeda, F. J., and Ventanas, J. (1999). Dry cured Iberian ham nonvolatile components as affected by the length of the curing process. Food Research International, 32: 643-651.

Simon-Sarkadi (2019). Amino acids and biogenic amines as food quality factors. Pure and Applied Chemistry, https://doi.org/10.1515/pac-2018-0709.

Toldrá, F. (2002). Dry-cured meat products. John Wiley \& Sons. ISBN 0-917678-54-0.

Toldrá, F. (2006). The role of muscle enzymes in dry-cured meat products with different drying conditions. Trends in Food Science and Technology, 17: 164-168.

Virgili, R., Saccani, G., Gabba, L., Tanzi, E., and Soresi, B. C. (2007). Changes of free amino acids and biogenic amines during estende ageing of Italian dry-cured ham. LWT - Food Science and Technology, 40(5): 871-878.

Open Access. This is an open-access article distributed under the terms of the Creative Commons Attribution 4.0 International License (https://creativecommons.org/licenses/by/4.0/), which permits unrestricted use, distribution, and reproduction in any medium, provided the original author and source are credited, a link to the CC License is provided, and changes - if any - are indicated. (SID_1) 